\title{
Torah as Wisdom in 4 Ezra and 2 Baruch
}

\author{
Lydia Gore-Jones \\ St Andrew's Greek Orthodox Theological College, Surry Hills NSW, Australia \\ lgorejones@gmail.com
}

\begin{abstract}
This essay is concerned with the meaning of torah and its relationship with wisdom in late Second Temple Judaism. It has been previously argued that, as the Mosaic torah had gained dominance, the wisdom school absorbed and accommodated the Mosaic torah tradition, and yet maintained all the essential elements of the sapiential tradition. Through a study of two Jewish apocalypses, 4 Ezra and 2 Baruch, the essay discovers not only the sapientialization of the Mosaic torah, but also the total submission of the wisdom tradition under the authority of the Mosaic torah tradition to gain legitimacy. It argues that this is done through a submission of sapiential revelations to the Mosaic revelation received at Sinai, and a portrayal of wisdom recipients and apocalyptic visionaries as types of Moses. This process reflects religious innovation under the disguise of compliance with established, older traditions.
\end{abstract}

\section{Keywords}

Wisdom tradition - Mosaic tradition - apocalypses - Second Temple Judaism apocrypha - pseudepigrapha - revelation - religious innovation

\section{Introduction $^{1}$}

"Torah" is a central theme of ancient Judaism, yet it is also such a polysemic concept that defining it has proven to be a challenge. By the end of the Second Temple period, as torah became increasingly spoken of as divine wisdom, it

1 This is a substantially revised version of the paper that was awarded the Compendia Rerum Iudaicarum ad Novum Testamentum (CRINT) Essay Prize in 2019. The author wishes to thank the support received from the CRINT Foundation, especially for providing the funds to make this article available in Open Access. 
had become an even more multi-faceted concept that demands further elucidation. Torah became more than ever a "trademark" of Second Temple Judaism, but what exactly does it mean? It was a common theme that kept diverse traditions connected, but how did it achieve that?2 Particularly, what was its relationship with wisdom? ${ }^{3}$ It has been suggested that, as the Mosaic torah had gained dominance, the old wisdom tradition adopted a new paradigm without changing much of its wisdom content; even torah was "sapientialized" and taken under the all-encompassing concept of wisdom. ${ }^{4}$ One influential explanation of this relationship is the model proposed by Jack T. Sanders. Using the sociological theory of Berger and Luckmann to explain the phenomenon of the coexistence of competing religious paradigms, ${ }^{5}$ Sanders concludes that the wisdom school absorbed and accommodated the Mosaic torah tradition, yet maintained all the essential elements of the sapiential tradition. ${ }^{6}$ Not all, however, are in agreement with Sanders. Others offered interpretations of texts in Sirach and Dead Sea Scrolls that show the "domestication" of wisdom under the category of torah. ${ }^{7}$ Since most previous studies have dealt with sapiential texts, it is the purpose of this paper to revisit the question through a study of the concept of "torah" in two Jewish apocalyptic works written around the end of the first century CE, 4 Ezra and 2 Baruch. ${ }^{8}$

2 In Schipper and Teeter's words, "the intersection of these two complex and multifaceted concepts" becomes "a crucial nexus for understanding late post-exilic Jewish thought and literary production" ("Introduction," 2).

3 For a full survey of wisdom literature in the Second Temple period on the subject of the relationship of wisdom and Mosaic torah, see Eckhard, Law and Wisdom. Another work offering comprehensive background knowledge is Collins, Jewish Wisdom.

4 See, for example, Sheppard, Wisdom as Hermeneutical Construct; Nickelsburg, "Torah and Deuteronomic Scheme," esp. 232-33; Collins, Jewish Wisdom, 55; Blenkinsopp, Wisdom and Law, 162-63.

5 See Berger, Sacred Canopy; and Berger and Luckmann, Social Construction.

6 Sanders, "Sacred Canopies Collide."

7 For example, see Kaiser, “Covenant and Law," 237. Tooman (“Wisdom and Torah," esp. 226-27) argues that wisdom is subsumed by torah in 4Q525 (4QBeatitudes) and 4Q185 (4QSapiential Work). Similarly, Uusimäki (Turning Proverbs, 265) also observes the "torahization process of 4Q525"; however, she at the same time notes that "the concept of הרות is used in a rather abstract way to describe the pious orientation of the wise life — not in regard to detailed halakic discussion. The author wishes to lead the audience into a solid life led according to tôrâ (cf. the Greek prologue to Sirach), but this is done through means that are natural to poetic literature and in a manner that is apt in the reflective wisdom context" (267-68).

8 Fourth Ezra is also known as chs. 3-14 of Second Esdras; Second Baruch is also known as the Syriac Apocalypse of Baruch. Information regarding their provenance, textual traditions and content can be found in several commentaries. For 4 Ezra see Longenecker, 2 Esdras; Metzger, "Fourth Book of Ezra"; Knibb, "Second Book of Esdras"; and esp. the commentary 
The reason why 4 Ezra and 2 Baruch are ideal examples for this study is three-fold. Firstly, it is believed that both works represented Jewish response to the destruction of Jerusalem and the Second Temple in $7 \mathrm{O} \mathrm{CE}$. Their response was torah obedience in a clearly defined eschatological context. Thus they provide rich material for analysis of their respective author's understanding of the meaning and significance of torah for a religious community in deep crisis. In this way, they serve as ideal samples for a study of how religious change and innovation were instigated without being presented as a challenge to older traditions. ${ }^{9}$ Secondly, both 4 Ezra and 2 Baruch belong to the apocalyptic literary genre, which itself was a product of the amalgamation of diverse traditions in the Second Temple period. Although debate over its origins is far from being settled, both prophecy and wisdom have been identified as key influences. ${ }^{10}$ Fourth Ezra and Second Baruch represent the apocalyptic genre at its pinnacle at the close of the Second Temple period. In addition, both apocalypses were fictitiously set in the period after the destruction of the First Temple in 586 ВСE by the Babylonians, and pseudepigraphically attributed to biblical Ezra and Baruch, two representative figures associated with torah and scribal traditions of the Hebrew Bible. Thus 4 Ezra and 2 Baruch also demonstrate continuity with Hebrew Scripture, in which both the Mosaic and sapiential traditions are embedded. Historically, scribal schools were likely to have played a crucial role in the transmission and integration of various traditions. The third and final reason for choosing 4 Ezra and 2 Baruch is their strategic position in time: situated at the conclusion of the Second Temple period, they are a precursor to both Rabbinic Judaism and early Christianity. The close affinity of the two apocalyptic works to rabbinic circles has been well observed by several scholars. ${ }^{11}$ On the other hand, both apocalypses were preserved by

by Stone, Fourth Ezra. For 2 Baruch, see Bogaert, L'Apocalypse syriaque; Gurtner, Second Baruch; Klijn, "2 Baruch"; esp. Henze, Jewish Apocalypticism.

9 Thus their study is related to the wider phenomenon known as "rewriting scriptures," discovered both within the established canon (often referred to as "inner-biblical exegesis") and in extra-biblical writings (e.g., apocrypha, pseudepigrapha, Dead Sea Scrolls, etc.).

10 Representing the view seeing apocalyptic literature as a child of postexilic prophecy is Hanson, Dawn of Apocalyptic; see also Collins, "Prophecy to Apocalypticism." The other side of the debate is represented by von Rad, who proposes a wisdom source for apocalyptic. See his Theologie, 2:315-30. For a summary of different views, see Collins, Apocalyptic Imagination, 19-37.

11 Longenecker ("Locating 4 Ezra"), for example, locates 4 Ezra in the mainstream, rabbinic context, identifying the author as an authoritative figure among the ranks of the early rabbinic leaders at Yavneh. Bogaert (L'Apocalypse, 222-41), on the other hand, has produced detailed comparisons of 2 Baruch with Pesiqta Rabbati. 
Christian churches and were once treated as authoritative texts. ${ }^{12}$ Therefore, the understanding of torah and wisdom in 4 Ezra and 2 Baruch also foreshadows later Jewish and Christian development of these traditions.

Before turning our attention to the two apocalypses, however, it is necessary to briefly review the semantic trajectory of torah in the Hebrew Bible and in the Second Temple period before 4 Ezra and 2 Baruch, especially in relation to the wisdom tradition.

\section{Torah in the Hebrew Bible and Apocrypha}

In the Hebrew Bible, three distinct meanings may be delineated, although in many cases the word tôrâ is used with various shades and nuances..$^{13}$ Firstly, tôrâ used in wisdom literature in the Hebrew Bible seems to have little legal or covenantal connotation, but refers to its basic meaning of "teaching" or "instruction," in terms of Israel's age-old wisdom of how to lead a good and moral life. Such is the case with Proverbs, where tôrâ simply means good and sound teaching from a wise elder, parent or teacher of wisdom. ${ }^{14}$

The majority of use of tôrâ in the Hebrew Bible, however, is found in the Pentateuch, in close association with instructions of legal rulings-especially cultic rulings, divinely inspired and mediated through Moses. ${ }^{15}$ Most significantly in Deuteronomy, tôrâ represents more prominently the divinely inspired teachings of Moses, thus the embodiment of God's covenant with the nation of Israel. ${ }^{16}$ In addition, tôrâ is specifically presented as a written law code in the form of a book. ${ }^{17}$ This also applies to writings of the so-called Deuteronomic

12 By "authoritative" I mean they held positions of prestige and influence. While 4 Ezra was part of the deuterocanonical apocrypha as chs. 3-14 of 2 Esdras, the extant complete text of 2 Baruch belongs to the oldest codex of the Syriac Bible (manuscript 7a1 of Bibliotheca Ambrosiana). Additionally, sections of the apocalypse are also found in four Jacobite lectionaries. A different version of the Epistle of Baruch (chs. 78-86) was canonized by ancestral communities in the Syriac Orthodox ecclesiastical tradition. For more details, see Gurtner, Second Baruch, 6-10, and more bibliography on 2 Baruch's manuscript history therein.

13 For a thorough study of the meanings of tôrâ in the Hebrew Bible, see Östborn, Tôrâ.

14 Prov 1:8; 3:1; 4:2; 6:20; 13:14; 28:4, 9; 29:18; 31:26.

15 E.g., Exod 12:49; Lev 7:7, 37; 14:54; Num 5:30; 15:16, 29; 19:2, 14; 31:21.

16 It is generally agreed that tôrâ as a definite noun is best translated "law." This usage appears mainly in the Pentateuch, Deuteronomic history and priestly writings. Examples

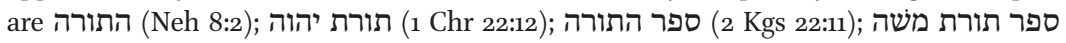
(Neh 8:1); ספר תורת יהוה ביד משורה (2 Chr 34:14); etc. See Hogan, "tôrâ in 4 Ezra," 531. 
school, such as the books of Joshua, 2 Kings and Jeremiah. ${ }^{18}$ This emphasis on tôrâ being Mosaic commandment, covenant, and the book of law is continued in priestly writings such as 1-2 Chronicles after the return from the Babylonian exile. ${ }^{19}$ While the Mosaic origin of tôrâ is maintained, there is even a more distinctively cultic perspective: the torah is the law maintained and taught by the priestly class. The same perspective is also accentuated in Nehemiah, Zephaniah and Haggai. ${ }^{20}$

The wisdom and legal traditions aside, tôrâ also appears in the prophetic tradition represented by Isaiah, Micah and Habakkuk. Here tôrâ shares the same divine origin as in the legal tradition, yet it is devoid of any specific meaning of legal rules or Mosaic covenant, but takes on the broad sense of the "word of God" - the will and judgment of God in the form of divine oracles. ${ }^{21}$

In the postexilic period, a complex phenomenon further emerged, namely the convergence of the concepts of torah and wisdom. Admittedly, even in Deuteronomy is the Mosaic torah once spoken of with wisdom colouring:

Behold, I [Moses] have taught you statutes (חקים) and ordinances (משפטים), as the LORD my God commanded me, that you should do them in the land which you are entering to take possession of it. Keep them and do them; for that will be your wisdom (חכמה) and your understanding (בינה) in the sight of the peoples, who, when they hear all these statutes (חקים), will say, "Surely, this great nation is a wise (חכם) and understanding (נבון) people."

Deut 4:5-6 Rsv

This evidence led Weinfeld to attribute the shift of the meaning of tôrâ from "teaching" in the wisdom tradition to "law" in a legal and covenantal sense to Deuteronomy. ${ }^{22}$ Similarly, Blenkinsopp observes that "Israelite law can be seen as a specialization of clan wisdom." ${ }^{23}$ In a more recent study on Deut 4:5-8, Krüger concludes that, although Deut 4:6 is not a statement about the relationship between wisdom and torah in principle, law is already presented as an object of teaching and learning, indicating "the transformation of the law into sapiential teaching of life. ${ }^{24}$ Not only in Deut 4:5-8, which is the sole text in

\footnotetext{
18 Josh 1:7, 8; 8:34; 22:5; 2 Kgs 17:13; 21:8; 22:8, 11, 23:24; Jer 2:8; 18:18; Lam 2:9.

191 Chron 22:12; 2 Chr 14:3; 15:3; 19:10; 33:8; 34:15, 19.

$20 \quad$ Neh 8:1-3; 12:44; 13:3; Zeph 3:4; 7:12; Hag 2:11.

21 E.g., Isa 2:3; 8:6; 42:21; 51:4; Mic 4:2; Hab 1:4.

22 Weinfeld, Deuteronomy, 244-319.

23 Blenkinsopp, Wisdom and Law, 151.

24 Krüger, "Law and Wisdom," 43, 52.
} 
the Pentateuch where wisdom and torah are related to each other, ${ }^{25}$ the word חכם occurs even in the legal core of Deuteronomy (16:19-20), and the Mosaic commandment seems to be a reformulation of the sagely admonition in Prov 21:21, demonstrating subtle influences of wisdom on torah. ${ }^{26}$

There is also argument, however, that the direction of influence is from Deuteronomy to Proverbs, from torah to wisdom. Building on the correspondences between Prov 6 and Deut 6 discovered by Michael Fishbane, ${ }^{27}$ Bernd Schipper argues that in addition to Prov 6, other passages in Proverbs, especially Prov 3 and Prov 7 , show influences of Deuteronomy through allusions to the Shema Yisrael in Deut 6 (paralleled in Deut 11), the Decalogue formula, and a range of Deuteronomic or Deuteronomistic terminology. ${ }^{28}$ For Schipper, the composite nature of the book of Proverbs, especially the later layers of text in Prov 1-9 and 30-31, reflect the different views on the conceptions of wisdom and torah. This, he argues, can be connected further to a theological discourse (debate?) about the relationship between wisdom and torah in the postexilic period, which shaped the composition and redaction of Proverbs. ${ }^{29}$ Schipper argues that by using the same key words in the passage of Deut 6, "the מצוה of תורה of תורה of the mother (in Proverbs) comes close to the and the and מצוה of God"; and just like the Israelites in Deut 6:7//11:18 are instructed to teach the words of God to their sons, so in Proverbs children are also educated by their parents. ${ }^{30}$ The idea of an interaction between the legal tradition and the sapiential tradition is significant, but the difficulty is how to establish with certainty that מצוה mean the same for Deuteronomy and Proverbs. Whether the author(s)/redactor(s) of Proverbs also used the word tôrâ to mean Mosaic law is far from being certain. These intertextual associations certainly shed more light on the developing relationship of wisdom and torah, but it is also important to note the differences: in Proverbs, tôrâ is devoid of Mosaic origins and covenantal connotations, and seems to be synonymous to wisdom teaching.

Clear evidence for a confluence of the torah of Moses and wisdom emerges from two most commonly quoted examples of sapiential texts: Sirach and 1 Baruch. Sirach 15:1, for example, equates wisdom with the torah in such terms: "The man who fears the Lord will do this, and he who holds to the law (vónov)

\footnotetext{
25 Krüger, 35 .

26 Müller, "Blinded Eyes." Müller notices that חכם and cognates appear four times in Deuteronomy: 1:13-15; 4:5-8; 16:18-20; 34:9.

27 Fishbane, "Torah and Tradition," 284.

28 Schipper, "When Wisdom."

29 Schipper, $70-75$

30 Schipper, 6o.
} 
will obtain wisdom" (RSV). In Sir 24, wisdom speaks, echoing the words of Lady Wisdom in Prov 8; yet Ben Sira's wisdom "is the book of the covenant of the Most High God, the law (vónos) which Moses commanded us as an inheritance for the congregations of Jacob" (24:23 RSV). ${ }^{31}$ First Baruch 4:1 clearly makes the same equation: "She [wisdom] is the book of the commandments of God, and the law (vónos) that endures for ever" (RSV). While there is no doubt that for Ben Sira (and 1 Baruch) torah refers to the Mosaic torah, it is clear that he did not cite any specific texts or rulings in the Pentateuch, but rather turned torah into a source for wisdom instruction in his pedagogical programme. ${ }^{32}$

This consistent lack of interest in any halakhic prescriptions and legal commandments is also evidenced in a wide range of wisdom literature of this period, of which Sirach and 1 Baruch are part. When the term tôrâ is used, it denotes rather torah piety. John J. Collins, for example, indicates how Aramaic texts found at Qumran show an overwhelming concern for wisdom instruction rather than prescriptive law. Increased prominence of halakhic disputes, according to him, only occurred after the Maccabean revolt within the confine of sectarianism. ${ }^{33}$

The absorption of torah into wisdom also seems to be borne out by the socalled "torah-wisdom psalms" in the Psalter, for instance, Pss 1, 19, and 119. These psalms are dated to the postexilic or Second Temple period because of their "anthological" style; ${ }^{34}$ that is to say, "creating Scripture through the creative use of Scripture" - a corpus of authoritative texts in their days. ${ }^{35}$ The 176 -verse long acrostic Ps 119 is a particularly interesting example. The word tôrâ appears twenty-one times; at the same time, the psalm shows a strong concern for commandment keeping, revealing its conceptual as well as lexical borrowing from Deuteronomy, especially the paraenetic text of Deut 4:1-6. ${ }^{36}$ The meaning of tôrâ with its synonymous terms in Ps 119 has been interpreted in diverse ways. ${ }^{37}$

31 There is an abundance of scholarly works on the relationship of wisdom and torah in Sirach. See the long list in Wright, "Sapiential Pedagogy," $157-58$ n. 3.

32 Wright, 159, 168, comments that torah in Sirach is one of several sources of wisdom, albeit an indispensable one. Torah at this stage remained a malleable concept.

33 See Collins, "Transformation of Torah."

34 Or "anthologische Stilgattung," using the term of Deißler, Psalm 119, 268, 277. For the dating of the wisdom psalms, see also Levenson, "Source of Torah," 566.

35 Botha, "Interpreting 'Torah."

36 This is demonstrated by Ps 119's constant use of ideas and vocabulary characteristic of Deuteronomy, such as "to keep," לשמר (vv. 4, 5, 9, 57, 60, 106); "to do," לעשות (vv. 112, 121, 126); "meditate," שיח (vv. 15, 23, 27, 48, 78, 97, 99, 148); "not forget," לא שכמת (vv. 16, 61, 83, 93, 141, 153, 176).

37 These terms are "testimonies," עדות; "precepts," פקודים; "statutes," חמשרים; "commandments," מצות; "judgments," משפטים; "word," דברה; "utterance," דרכקודים "ways, דרים; and "path," מצרח. 
For Deißler, it refers to a written text to be read and meditated upon, which encompasses all scriptures. ${ }^{38}$ While Seybold excludes the possibility for tôrâ to mean a book or books, ${ }^{39}$ Freeman believes that it could refer to revelation of God's will in an undisclosed written text. ${ }^{40}$ On the other hand, Zenger points out the lack of decisive connotation of Mosaic torah, concluding that torah here refers to a dynamic and open category of the revelation of divine will. ${ }^{41}$ Indeed, despite the apparent influence of Deuteronomy, the psalm makes no mention in its 176 verses of any of the three fundamental Deuteronomic elements: the covenant, Moses, and torah as a book. ${ }^{42}$ This absence of interest leads Levenson to conclude that the psalm is closer to Proverbs in its understanding of wisdom and torah than to Deuteronomy. ${ }^{43}$ In fact, the psalmist adopts the sapiential attitude to wisdom as he talks about torah. ${ }^{44}$ As wisdom, torah is taught and learned, delighted in, sought after. According to Ps 119, not only does torah have a steering function like that of wisdom in the life of the righteous, ${ }^{45}$ torah is defined in terms of wisdom. Of course, "wisdom" here refers not to the wisdom literary genre, but rather a mode of perception, a lens through which all other thoughts are interpreted and expressed. ${ }^{46}$

A brief survey of wisdom literature of the Second Temple period in the form of torah piety seems to offer overwhelming support to Sanders's theory; that is, the wisdom school largely absorbed and accommodated the Mosaic torah tradition, yet maintained all the essential elements of the sapiential tradition. But what about 4 Ezra and 2 Baruch? To the two apocalypses we shall now turn.

\section{Torah as Wisdom in 4 Ezra and 2 Baruch}

\subsection{Torah Seen through the Lens of Wisdom}

As response to the deep crisis brought about by the destruction of the national cultic centre and to the threat of a loss of covenantal relationship, both 4 Ezra

\footnotetext{
38 Deißler, Psalm 119, 296-97.

39 Seybold, Psalmen, 473.

40 Freedman, Psalm 119, 91-92.

41 Zenger, "Torafrömmigkeit," 387.

42 Levenson, "Source of Torah," 564-66.

43 Levenson, 567.

44 The "I" in Ps 119, according to Finsterbusch ("Yahweh's torah"), speaks from different life perspectives, representing various stages of life and experiences; thus it encompasses the entirety of faith and life for the nation in the Hellenistic period.

45 This function of torah in Ps 119 is emphasized by Reynolds, Torah as Teacher, esp. 183.

46 Similarly, Sheppard calls it a "hermeneutical construct" (Wisdom as Hermeneutical Construct).
} 
and 2 Baruch are an urgent call to Israel for a return to the Mosaic torah. Words

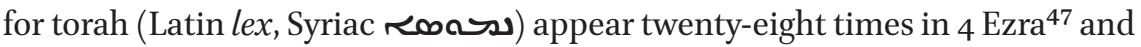
forty-two times in 2 Baruch, ${ }^{48}$ demonstrating the authors' deepest concern for torah obedience. On the other hand, both apocalypses show an unmistakable sapiential outlook; their affinity to wisdom books and the wisdom tradition, such as Job, Proverbs, Qoheleth, and torah-wisdom Psalms, has been explored in many previous studies. ${ }^{49}$ In 4 Ezra and 2 Baruch a similar pattern is discernible: there is a lack of specific discussion of commandments and halakhic rules; instead, torah obedience is expressed in terms of pursuing knowledge and striving to obtain divine teaching. The strong sapiential inclination in both apocalypses is clearly visible in two ways: that torah is identified as wisdom and talked about in sapiential terminology; and that each protagonist is portrayed as a seeker or a teacher of wisdom.

\subsubsection{Ezra}

"Torah" in 4 Ezra, like in Sirach, 1 Baruch, and the "torah-wisdom Psalms" such as Psalm 119, is equated with wisdom, and its interpretation rendered in synonyms with wisdom. Torah is frequently referred to as "the way(s) of the Most High"; 50 other terms used as parallels to torah and wisdom are "commandment(s)" (4 Ezra 3:19, 36; 7:37, 45, 72), "judgment" (5:34, 40, 42; 7:44), "righteousness" (8:12), "statues" (7:11, 24; 9:23; 13:42), "works" (7:24), "decree" (10:16), "words" (14:6), "path" (14:22), and "knowledge" (14:47). Here, as in Psalm 119 , torah is regarded as a "comprehensive arch-lexeme" 51 which includes guidance for life, wonders of nature and creation, God's past dealings with Israel, his future plan and his will. This knowledge of God's torah is compared to a seed sown in Israel's heart to produce fruits (9:31); Ezra pleads God to give his

According to the count of Hogan, "tôrâ in 4 Ezra," 534, n. 17. 4 Ezra 3:19, 20, 22; 4:23; 5:27; 7:17, 20, 24, 72, 79, 81, 89, 94, 133; 8:12, 29, 56; 9:11, 31, 32 (2x), 36, 37, 38, 54; 14:21, 22, 3 .

48 See "Syriac Concordance" in Gurtner, Second Baruch, 179. 2 Bar. 3:6; 15:5; 17:4; 19:3; 32:1; 38:2, 4; 41:3; 44:3, 7, 14; 46:3, 4, 5; 48:22, 24 (2x), 27, 38, 40, 47; 51:3, 4, 7; 54:5, 14; 57:2; 59:2, 4, 11; 66:5; $67: 6 ; 77: 3,15(2 \mathrm{x}), 16 ; 84: 2,5,8,9 ; 85: 3,14$.

49 For instance, the influence of Job in 4 Ezra is well studied in Knibb, "Apocalyptic and Wisdom." A more recent study of 4 Ezra, Hogan's Theologies in Conflict, frames the issues under discussion straight as a "wisdom debate." Her excellent article, "tôrâ in 4 Ezra," also discusses 4 Ezra's understanding of "torah" in a wisdom debate context. I disagree with the wisdom debate approach to interpretation, however, as I see 4 Ezra as a coherent whole, expressing one view of "torah" as the author's response to the destruction of the Temple. Second Baruch's wisdom link with Proverbs, Daniel, Job and Qoheleth is explored by Kim, "Wisdom and Apocalyptic"; and Henze, "Qoheleth and Syriac Apocalypse."

50 E.g., 4 Ezra 4:2, 11; 5:24; 7:79, 88-89, 129; 8:56; 9:9; 12:4; 13:54; 14:31.

51 The term is Botha's; see "Interpreting 'Torah." 
people a seed for the cultivation of "understanding" (8:6). This torah/wisdom is also compared to food and drinks to be absorbed, as Ezra bids his own soul, "drink your fill of understanding, O my soul, and drink wisdom, O my heart!" (absorbe, anima mea, sensum, et bibe, cor meum, intelligentiam) (8:4; RSV).

But what exactly is this torah/wisdom that Ezra is seeking? Like in Sirach, so in 4 Ezra torah is identified as divine wisdom; in particular, torah is the law given at Sinai, a book/books of covenant. (See more on this in the next section.) The destruction of Jerusalem and the temple triggered the covenant crisis, which led 4 Ezra to a cry for the restoration of the torah. However, the actual revelation given to him for such revival is not legal rulings to be obeyed but rather esoteric knowledge about the "last things": the coming of the end (4:26-50; 6:1-10), the eschatological signs ( $5: 1-13 ; 6: 10-28)$, the stages of endtimes (7:26-43), and post-mortem experiences of the righteous and the wicked $(7: 78-115)$. The instruction (tôrâ) is not only given in the aural mode through dialogues with the angel Uriel - a wisdom teacher type of figure-but also in the visual mode in apocalyptic visions: the heavenly Jerusalem (10:25-59), a messianic figure in the image of a lion defeating the enemy in the image of an eagle (12:1-34), and a son of man figure reproving the nations and restoring the tribes of Israel (13:1-53). In the narrative all these things would then be written down and counted as God's torah.

Not only is the angel Uriel presented as a wisdom teacher, Ezra, the protagonist of the apocalypse, is also portrayed as a sapiential figure. ${ }^{52}$ No doubt the biblical Ezra, the second giver of the law, is the intended pseudonymous mouthpiece; ${ }^{53}$ yet Ezra is first and foremost characterized as a seeker of wisdom. He engages the angel Uriel in three dialogues to inquire about the reason for Israel's afflictions and what the future holds; he prays and fasts in order to know God's will and the eschatological secrets. It may have been for this reason that the pseudonymous hero Ezra is given the alternative name of Salatiel (from Hebrew שאלתיאל, "I have asked God") at the beginning of the book. ${ }^{54}$ Throughout the apocalypse he lives up to it, as he stubbornly demands to comprehend (3:31), strives to understand ( $4: 12 ; 5: 34 ; 8: 4)$, searches out the way of the Most High (12:4), beseeches (4:22; 5:56; 12:6; 13:13), and inquires (4:23). The way Levenson sums up the image of the psalmist in the torah-wisdom Ps 119 also fits Ezra perfectly; he is one whose exclamations are constantly heard

$5^{2}$ For a more detailed description of the portrayal of Ezra, see Gore-Jones, "Unity and Coherence."

53 Ezra is called the "scribe of the knowledge of the Most High forever" (4 Ezra 14:50), indicating that it is the biblical Ezra the scribe.

54 At the beginning of the book, the protagonist is introduced as "I, Salathiel, who am also called Ezra (3:1)." 
throughout the book: "Teach me!" "Reveal to me!" "Make me understand!" "Grace me with your torah!" "Give me wisdom!"55 Psalm 119 differs, of course, in not giving a hint about what God's "way" and "judgment" is. Ezra, on the other hand, is also like the sagely Job, whose questions are not answered directly, but who is given a glimpse of unfathomable divine mysteries.

Like the suffering Job in a heap of ashes, Ezra lies in bed (3:1), his spirit is "greatly agitated" (3:3). Like the obstinate Job, Ezra questions God. His question about Israel's torah-based covenant is couched in a sapiential problem of theodicy: "how thou dost endure those who sin, and hast spared those who act wickedly" (3:30); "are the deeds of Babylon better than those of Zion?" (3:31). Also like Job, Ezra is tested with a series of riddles and quizzes about wonders of nature, ${ }^{56}$ and the problem of Israel's covenant is turned into a sapiential question about human ability to understand divine wisdom (4:5-11; 5:36-40): "how then can your vessel comprehend the way of the Most High?" (4:11). The portrayal of Ezra the law giver in 4 Ezra shows that, although torah may be the central key, its pursuit and its teaching are carried out in the sapiential style, as the pursuit and teaching of divine knowledge, especially the esoteric type.

When Ezra has eventually proved himself worthy to be the conduit of divine revelation of the torah, he is praised by the Most High for being one that has sought after wisdom: "because you have forsaken your own ways and have applied yourself to mine, and have searched out my law; for you have devoted your life to wisdom, and called understanding your mother" (13:54-55). ${ }^{57}$ Ezra receives the torah as a cup "full of something like water, but its color was like fire" (14:39). After he has drunk it, "my heart poured forth understanding, and wisdom increased in my breast, and my spirit retained its memory; and my mouth was opened, and was no longer closed" (14:40-41). "The cup" can certainly be interpreted as holy spirit too (14:22), but it is hard not to think that here 4 Ezra is imitating Ezek 3:3, where Ezekiel is given a scroll to eat before he begins to prophesy. Ezra then dictates, as a prophet utters oracles, the content of torah to five chosen scribes to write down in ninety-four books, including twenty-four books for both "the worthy" and "the unworthy," and seventy books of esoteric knowledge for the eyes of the wise and worthy (14:45-46).

The great importance attached to writing in 4 Ezra must be noted. It is Ezra himself, in the great finale of the apocalypse, who requested that the law be written again (14:22), because it "has been burned" (14:21; also 4:23 "the

55 Levenson, "Sources of Torah," 564.

$5^{6}$ On the similarity to Job, see Knibb, "Apocalyptic and Wisdom," 65-66.

57 English translations in this paper are, unless otherwise indicated, taken from Stone and Henze, 4 Ezra and 2 Baruch. 
written covenants no longer exist"), presumably in the fire of destruction. This statement finds its basis in Lam 2:9, "tôrâ is no more" (אין תורה); however, in Lamentations' context, tôrâ refers to teachings and instructions from Judah's king, princes and prophets (Lam 2:9), hence the NRSV translation of it as "guidance is no more." For 4 Ezra, however, what has been lost is not only guidance, but more precisely the covenant in written form. The rewriting of the law may certainly have some historical basis, as David Carr suggests that later scriptures were mainly the works of scribes of the exile from "memorized building blocks," thus containing radical reformulations of older traditions. ${ }^{58}$ But in 4 Ezra, the symbolic meaning of such a written torah is more significant. If the covenant and the nation's future must be recovered in the absence of the temple, ${ }^{59}$ the recovery then must be enacted in writing and embodied in books.

The number of twenty-four books to be made accessible to all is often compared with the mention of twenty-two books "containing the record of all time, which are rightly trusted" by Josephus (C.Ap. 1.38), as referring to an established "canon." Mroczek, however, argues that the number should be understood symbolically, rather than strictly realistically. ${ }^{60}$ Just like the acrostic Ps 119 using every letter of the Hebrew alphabet, 4 Ezra also uses the number to express "completion and coherence," ${ }^{1}$ "the minimal number of units with which every meaningful utterance may be formed."62 Equally significant is the number of the seventy books only for the "wise." No doubt, seventy here symbolizes the totality of knowledge. ${ }^{63}$

With the writing taking place, the coming together of torah and wisdom occurs on the central character of Ezra, who is called "the scribe of the knowledge of the Most High forever" (14:50). The formation of wisdom/torah is instrumented by scribes (e.g., Ezra's five assistant scribes) and its transmission is also through those who are trained to read and write, called "the wise." 64 It is also interesting how Ezra the scribe figure in the apocalypse combines the three traditional offices of sage, lawgiver, and prophet in one. It is noteworthy as well that they are expressed in a common sapiential parlance, as the Most High declares, commenting on the content of the seventy secret books, now also part of his torah, that "in them are the springs of understanding, the

\footnotetext{
58 Carr, Tablet of Heart, $167-86$.

59 Or, in Najman's (Losing the Temple) term, a "reboot."

6o Mroczek, Literary Imagination, 166.

61 Mroczek, 166.

62 Najman, Losing the Temple, $15^{2}$.

63 Hogan, "tôrâ in 4 Ezra," 549-5o n. 54; Najman, 152; Mroczek, Literary Imagination, 166.

64 E.g., see 4 Ezra 12:37-38, the teaching of the eschatological secret is to the wise through a book to be hidden.
} 
fountains of wisdom, and the river of knowledge" (14:47). Torah is thus one entity encompassing law, secret revelations, spoken prophetic words, and written books - ultimately God's wisdom.

\subsubsection{Baruch}

Second Baruch's call for a return to the torah is even louder and clearer than 4 Ezra's. The significance of torah is aptly summed up in the final episode, Baruch's epistle to his people in diaspora: "we have nothing now except for the Mighty One and his torah" (85:3). Second Baruch also more closely associates torah with the Mosaic torah; nevertheless, as in 4 Ezra, its presentation of torah is still heavily coloured by sapiential vocabulary. Torah is called by its synonyms such as "understanding" and "wisdom." ${ }^{65}$ One example will suffice. Echoing Deut 4:5-8, Baruch prays to God:

In you we trust, for see, your Torah is with us. And we know that we will not fall as long as we hold on to your statutes ... For we all are one renowned people who received one Torah from the One. And that Torah that is among us aids us, and the surpassing wisdom that is among us will help us.

2 Bar. 48:22-24

As torah is paralleled with wisdom, a teacher of torah, namely "son of the law"

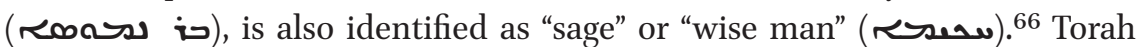
obedience is not understood as moral conduct only, ${ }^{67}$ for Baruch also urges the audience of his epistle to keep the "festivals," "Sabbaths," and "traditions of the law" (84:8-9). Nevertheless, torah observance is expressed overwhelmingly in the sapiential sense of torah piety, rather than halakhic matters. ${ }^{68}$

One also detects a strong sapiential flavour in 2 Baruch through the use of the "torah is light" metaphor. The biblical foundation of such a metaphor is specifically found in prophetic and wisdom literature, ${ }^{69}$ two traditions out of

$65 \quad$ E.g., 2 Bar. 15:5; 38:2-4; 44:14; 48:22, 24, 36, 38; 51:3-4; 77:16; etc.

66 See 2 Bar. 46:4, 5. This is a clear link with later rabbinic usage. (See Schnabel, Law and Wisdom, 159-6o.) Rabban Johanan ben Zakkai also used "sons of torah" to refer to the Sages. See the discussion in Rosenfeld, "Sage and Temple."

67 Schnabel, $157,159-61$, seems to think that practice of torah in 2 Baruch only concerns ethical conduct, with which I disagree.

68 Henze expresses the same view in his Jewish Apocalypticism, 225-26; and "Torah and Eschatology," 205 .

69 Isa 2:5; 5:20; 45:7; 8:20; 9:1; 10:17; 42:6; 49:6; 50:10, 11; 51:4; 6o:1, 20; Mic 7:8-9; Pss 18:29; 27:1; 36:10; 43:3; 119:105, 130; Prov 6:23; 13:9; 20:20; Dan 2:22; 5:11, 14; etc. 
which sprang the apocalyptic offspring. Second Baruch's torah-light metaphor bears closer affinity to wisdom writings such as Prov 6:23, "the commandment is a lamp and the torah a light," or torah-wisdom Ps 119:105, "your word is a lamp for my feet and a light to my path." The torah-light metaphor is not unique to 2 Baruch among other later Second Temple writings, ${ }^{70}$ but 2 Baruch confers upon it more significance through a systematic application of this metaphor throughout the book. The meaning and function of torah is expounded through the interwoven themes of light and darkness, Moses and Adam, and life and death. ${ }^{71}$ Through Adam's disobedience to God's commandment, death comes into the world like darkness; however, through Moses,

the lamp ( sat in darkness. It will make the promise of their reward known to those who believe, and the torment of fire to those who deny that is preserved for them.

2 Bar. 59:2

he [Moses] brought the Torah to the seed of Jacob and lit a lamp for the nation of Israel ... He who lit (נ口) [a lamp] took from the light ( Few are those who are like him. However, those many for whom he has lit (נ口) [a lamp] have taken from the darkness of Adam and have not taken delight in the light (

2 Bar. 17:4-18:2

Not only Moses, but also Baruch himself and Israel's future teachers prophesied by him are called bringers of light. When Baruch announces his departure from this world, the people lament,

Truly we will be in darkness, and there will be no light ( $<$ ims) for the people who are left. For where again shall we seek the Torah, or who will distinguish for us between death and life?

2 Bar. $46: 2-3$

$70 \quad$ The metaphor is also found, e.g., in 4 Ezra 14:21, 25; LAB 11:1; T. Levi 14:3-4; 18:3; T. Naph. 5:3-4; John 12:35-36; 2 Cor 4:4; 1 Thess 5:5; etc. Also see Henze, Jewish Apocalypticism, 208 n. 68. The Targumim consistently interpret the symbol of light as the Law. See Vermes, "Torah Is Light."

71 Gore-Jones, When Judaism Lost, 177-78. 
Baruch's reply is that "shepherds and lamps" come from the torah. Prophets and teachers pass, but the torah abides. "If, therefore, you look to the torah and will be heeding wisdom, the lamp will not be wanting and the shepherd not departing (77:15-16)." Not only is torah synonymous with wisdom, the giving and teaching of torah is also expressed within the context of seeking and learning wisdom.

Similar to 4 Ezra then, 2 Baruch also believes that the future of Israel remains with the scriptures. However, it shows a radically different understanding about how revival and adaptation must be carried out. For 4 Ezra, "torah is no more," and must be rewritten and substantially expanded. In the words of Mroczek, "in 4 Ezra, where the torah had become unavailable or unintelligible, it is not exegesis that is the solution, but entirely new revelation, beside and far beyond any established canonical corpus." ${ }^{72}$ For 2 Baruch, in contrast, the torah "is with us" (48:22), "among us" (48:24) and "not hidden from us" (85:8). In the absence of the temple, future access to divine revelation will be through the sages who are the interpreters and teachers of torah, as lamps that carry light.

The light and darkness theme continues in the grand finale of Baruch's powerful vision of the "twelve bright and dark waters" (53:1-74:4). In it he sees the entire human history, especially biblical history, divided into twelve periods, represented by bright and dark waters alternating, pouring down from a primeval cloud symbolizing time foreordained by God. More will be said about the vision in the following section; but here it suffices to note how the vision is in fact an extended version of the torah-light metaphor. The sole criterion for light and darkness of human history, thus "bright" and "dark," is whether torah is heeded and upheld. The systematic conceptualization of the light metaphor is better seen if the writing is read in Syriac. The noun "light" Rimo (18:1-2; 19:3; 46:2; 48:50; 51:3, 10), the adjective "bright" دino (53:5, 6; 57:1, 3; 59:1, 12; 61:1, 8; 63:1, 11; 66:1, 8; 68:1, 8; 69:5; 72:1; 74:4), and the verb "to shine, to be bright" J (17:4; 18:1; 21:18; 34:1; 38:1; 53:9; 54:5; 59:2; 77:13), are cognates of the same root, woven together in a network of an extensive metaphor.

Thus, whereas in 4 Ezra, torah is compared to a seed to be sown, or food and drinks to be consumed, in 2 Baruch torah is light that enables one to see the way, to dissipate darkness, to give life, and as a lamp to be passed down from Moses to Israel and their descendants. In both apocalypses, torah is understood less as laws and rules, but in terms of wisdom.

In this respect both 4 Ezra and 2 Baruch conform to Sanders's proposition that the Mosaic torah tradition was absorbed into the wisdom tradition, and was interpreted and articulated through the sapiential outlet. However, there 
is the other side of the coin, and this is an equally —if not more-significant development of Second Temple Judaism; namely, the total submission of wisdom under the supremacy of Moses. Both 4 Ezra and 2 Baruch also demonstrate this.

\subsection{The Supremacy of Mosaic Torah}

In both 4 Ezra and 2 Baruch, wisdom received in prophetic and apocalyptic revelations is made sure to also receive the imprimatur of Mosaic authority. (I include "prophetic" here because both apocalyptic visionaries are portrayed as the last prophet left to Israel; Ezra is called so explicitly [4 Ezra 12:42], whereas Baruch is a prophet because "the word of God was upon" him [2 Bar. 1:1; 10:1].) This is achieved in two ways also. On the one hand, the protagonists are cast as a type of Moses; and on the other hand, the revelations they receive are claimed to be part of the revelation at Sinai or the teachings of Moses in Deuteronomy.

\subsubsection{Ezra}

As I have stated above, torah for 4 Ezra has a broad range of meaning that encompasses divine revelation written and unwritten, and ultimately the wisdom of God. Nevertheless, 4 Ezra never departs from the conviction that torah foremost refers to the law of Moses and has its roots in Israel's Sinaitic tradition. In this sense, torah is another word for Israel's covenant and identity. The giving of the torah through Moses is described as an event with cosmic significance:

Thou didst bend down the heavens and shake the earth, and move the world, and make the depths to tremble, and trouble the universe. And thy glory passed through the four gates of fire and earthquake and wind and ice, to give the Torah to the descendants of Jacob, and thy commandment to the posterity of Israel.

$$
4 \text { Ezra 3:18-19 }
$$

Torah here is clearly associated with the Mosaic law, an identity marker that separates Israel, to whom God has given the torah (5:27), from the gentiles, those who "opposed" the torah (5:29). Torah is equated with the covenant (5:29).

How can the torah be both the law of Moses received on Mount Sinai and recorded in the Pentateuch, and the "new" revelations Ezra received regarding eschatological mysteries and the secrets of the afterlife of departed souls? In other words, is not there an obvious conflict of authority between the claim of the Mosaic torah and the claim of divine wisdom of Ezra's apocalyptic 
revelations? Not for the author of 4 Ezra. The apparent conflict is resolved through a two-step alignment.

Firstly, Ezra is portrayed as the second lawgiver in the likeness of Moses. God calls to Ezra "out of a bush," "Ezra, Ezra," to which Ezra replies, "Here I am, Lord" (14:1-2). This is a clear allusion to God's calling of Moses in Exodus (Exod 3:4). The author makes the parallel explicit by making the Most High himself recall his summon of Moses in the same manner:

I revealed myself in a bush and spoke to Moses, when my people were in bondage in Egypt; and I sent him and led my people out of Egypt; and I led him up to Mount Sinai. And I kept him with me many days.

4 Ezra 14:3-4

Now in the same manner, Ezra is kept from his people for forty days (14:23) before he is given the wisdom to dictate the entire torah, an intentional reference to the forty-day period in which Moses received the Ten Commandments (Exod 34:28). ${ }^{73}$ Ezra's farewell speech to his people also echoes the voice of Moses:

Hear these words, O Israel. At first, our fathers dwelt as aliens in Egypt, and they were delivered from there, and received the law of life, which they did not keep, which you also have transgressed after them. Then land was given to you for a possession in the land of Zion; but you and your fathers committed iniquity and did not keep the ways which the Most High commanded you. And because he is a righteous judge, he took from you what he had given in due time.

4 Ezra 14:28-32

The opening of the exhortation, "Hear these words, O Israel," recalls the Shema Yisrael in Deut 6:4 as the words of Moses, whereas the "law of life" brings to

73 Stone, Fourth Ezra, 35, 374, 431. Knowles ("Moses, Law and Unity," 261-65) points out that Ezra has previously spent forty days fasting before this final revelation, which is associated with Moses's forty days of intercession on behalf of the people after the Golden Calf episode (Deut 10:1-5, 10). If this is the case, there is a stronger connection in 4 Ezra with the Deuteronomic theme of sin, repentance and renewal, leading to the second giving of the torah. Hogan (Theologies in Conflict, 206 n. 5), on the other hand, indicates that Ezra's forty days of fast was spent not making intercessions but receiving revelations about the endtime; thus the two forty-day periods should correspond to the two forty-day periods when Moses was on the mountain with God according to Deut 9-10 or Exod 24:18 and 34:28. 
mind the Mosaic command, "Choose life for yourself, so that you may live!" (Deut 30:19). In other words, Ezra's farewell speech is a shortened imitation of Moses's valedictory exhortation in Deut 30:15-20.

Secondly, not only is Ezra modeled after Moses, the esoteric revelations he has received and now recorded in the seventy books for the wise and worthy are also grafted into the trunk of Mosaic tradition. At the calling of Ezra, the Most High recalls his own summons of Moses to Mount Sinai,

and I told him [Moses] many wondrous things, and showed him the secrets of the times and declared to him the end of the times. 'These words you shall publish openly, and these you shall keep secret.' And now I say to you: Lay up in your heart the signs that I have shown you, the dreams that you have seen, and the interpretation that you have heard.

4 Ezra $14: 5^{-8}$

In other words, the author is claiming that the apocalyptic revelations granted to Ezra had previously already been given to Moses. The esoteric part had been unknown because it had been concealed by God's command. There have been different interpretations of the theme of concealment that is present. Some understand this as reflecting the author's attempt to restrict esoteric knowledge to a select group; ${ }^{74}$ others see it as a device to solve the problem of pseudonymity. ${ }^{75}$ For our purpose here, it is clearly a literary strategy to reconcile the potential confrontation of the two torahs, one through Moses, and the other, Ezra. The secret motif makes it possible to include the "new" content of Ezra's torah into the Mosaic tradition. Although the revelation received by Ezra originated from divine wisdom, it is none other than an encore of the Sinai revelation established by Moses. The esoteric wisdom thus gains its credentials.

74 E.g., Longenecker ("Locating 4 Ezra," 292) argues that the author intends to prevent "social irresponsibility that results from fostering expectations concerning the destruction of one's overlord." Similarly, Moo (Creation, Nature and Hope, 155-56) interprets this as the author's attempt not to lead the simple-minded astray. However, 4 Ezra is not the only apocalypse in which one finds the secret motif. It is a common literary device in apocalyptic works, often used to solve the problem of pseudonymity and/or vaticinium ex eventu, and therefore, should not be taken literally. See Gore-Jones, "Unity and Coherence," 228-30.

75 Yarbro Collins ("Influence of Daniel," 111) indicates how the secret motif commonly goes hand in hand with pseudonymity. In Daniel, the protagonist is commanded to seal his visions (Dan 12:9); in Revelation, John is instructed, "Do not seal the words." The difference lies in the fact that Daniel is a pseudonymous fiction, whereas the problem of pseudonymity does not occur for John's Revelation. 


\subsubsection{Baruch}

The same process of double alignment also occurs in 2 Baruch: the teaching of Baruch is essentially the same teaching of Moses, and Baruch is the second Moses, the teacher of Israel. Second Baruch features three substantial public addresses as Baruch summons Israel to teach them the wisdom of God. Each of these is modeled after the rhetorical style of Mosaic speech in Deuteronomy:

Hear, O Israel, and I will speak to you, and you, seed of Jacob, listen, and I will instruct you. Do not forget Zion, but remember the sorrows of Jerusalem. For, see, days are coming and everything that is will be taken to destruction, and it will be as if it had not been.

2 Bar. 31:3-5

See, I will go to my fathers as is the way of all the age. But you, do not withdraw from the way of the Torah but keep [it] and warn the people who are left, lest they withdraw from the commandments of the Mighty One. For you see that he is just whom we serve, and our creator shows no partiality. See what has befallen Zion and what happened to Jerusalem.

2 Bar. $44: 2-5$

Hear, children of Israel, see how many you are who are left of the twelve tribes of Israel ... And see, you are here with me ... See, have you not seen what has befallen Zion?

2 Bar. $77: 2-8$

In particular, the way the discourses are introduced with commands such as "hear" and "see" is an imitation of the words of Moses in Deuteronomy (4:1; 6:4; 9:1; $27: 9$; and 30:15) ${ }^{76}$

Baruch's last days are also paralleled with those of Moses in Deuteronomy. ${ }^{77}$ The angel Remiel instructs Baruch about his preparation for departure from this world:

you will surely leave this world [or age], nevertheless not unto death but unto the preservation of times; ascend, therefore, to the top of this mountain, and all the places of this world will pass before you, the likeness of

$7^{6}$ For more on 2 Baruch's imitation of Deuteronomy in its rhetorical style, see Murphy, Structure and Meaning, 117-33; and Whitters, Epistle of Second Baruch, 156-68.

77 See also Henze, Jewish Apocalypticism, 104; Murphy, Structure and Meaning, 129; Sayler, Have Promises Failed, 97; and Allison, New Moses, 65-66. 
the inhabited world, the top of the mountains and the depth of the valley, the depth of the sea and the number of the rivers, that you will see what you are leaving where you are going. For this will befall after forty days.

2 Bar. $76: 2-4$

The similarities to the last days of Moses are hard to miss. As Moses is commanded to go up to Mount Nebo to see the promised land he is never to enter (Deut 32:49; 34:1-3), Baruch is to ascend a mountain to see the inhabited world he is to leave behind. Even Baruch's passing from this world to be preserved till the end-times (just as Ezra's translation in 4 Ezra 14:50) follows the well-known legend of the Assumption of Moses, which is now a lost document but whose title was mentioned in many early Christian lists of Jewish apocrypha. ${ }^{78}$

The strongest analogy between Baruch and Moses is found in the Epistle of Baruch (chs. 78-86). If the resemblances are only alluded to in the above examples, here Baruch explicitly draws a comparison between Moses and himself. He first reminds the people what Moses did: "Remember that Moses once solemnly called heaven and earth to witness against you and said: 'If you transgress the torah, you will be scattered, but if you keep it, you will be planted"' (84:2). Then he places himself directly as an imitator of Moses: "I, too, see, I say to you, that after you have suffered, if you obey those [things] that were said to you, you will receive from the Mighty One everything that has been set aside and preserved for you" (84:6). Moses called heaven and earth to witness (Deut 30:19), whereas Baruch calls his letter "a testimony" between "me and you" (84:7). As Moses is the intermediary between God and the people (Deut 30:15-16), Baruch also sees himself as charged by God to give an account for the people (84:7). As Moses leaves behind the book of the torah (Deut 30:10), Baruch instructs the people to "pass this letter and the traditions of the torah" on to later generations (84:9). ${ }^{79}$ Baruch's teaching, therefore, is not intended as new revelation to replace the Mosaic torah, but rather a restoration and reinforcement of the old.

We have seen above that 4 Ezra proposes an eschatological solution to the covenantal crisis and turns esoteric wisdom into torah, thus expanding the content of torah. Second Baruch, on the other hand, deals with the new crisis through a novel interpretation of the old Deuteronomic tradition. Second

78 See the lists in Russell, Method and Message, Appendix I, 391-95. Jude 1:9 testifies to the well-known tradition of archangel Michael having a dispute with Satan while receiving the soul of Moses.

792 Bar 84 is well noticed for Baruch-Moses parallelism in many studies of 2 Baruch. See, e.g., Henze, Jewish Apocalypticism, 105, and Allison, New Moses, 66. 
Baruch clearly adopts the Deuteronomic scheme of sin, punishment, repentance and renewal. The prologue (chs. 1-8) represents the "sin and punishment" stage, as God pronounces Israel's offences and destroys Jerusalem and the temple by the hands of his angels. Baruch's intercessions on behalf of the people and his speeches and epistle indicate that Israel is experiencing the stage of repentance, in anticipation of restoration and renewal. The repeated exhortation calling the people to prepare their hearts and souls for that which is to come strongly illustrates this point:

prepare your hearts and sow in them the fruits of the torah (32:1); prepare your hearts, so that you will obey the torah (46:5); prepare yourselves for that which is preserved for you, and be ready for the reward that is laid up for you (52:7); remove from your heart the vain error (78:6); prepare your hearts for that which you have believed from the beginning (83:8); if we direct and prepare our hearts, we will receive everything we have lost, many times over (85:4); let us prepare ourselves, so that we will possess and not be possessed, and that we will hope and not be put to shame (85:9); again, then, prepare yourselves (85:11)

But what is the reward waited for? Within the context of the catastrophic destruction of the Second Temple, it can hardly be the Deuteronomic promise of land, longevity and worldly prosperity. The wisdom of God Baruch has received reveals an imminent end of this age and the advent of a messianic era, followed by the age to come. Earthly prosperity is not entirely denied, but anticipated for in the messianic era; however, the life in this world promised in Deuteronomy is interpreted as eternal life in the age to come in 2 Baruch. How, then, does 2 Baruch propagate eschatological expectations while maintaining its faithfulness to the Deuteronomic worldview at the same time? The author extends the Deuteronomic horizon through a two-step adaptation. ${ }^{80}$

Firstly, longevity in itself is made of no value; instead, what matters are the benefits one's life brings to himself and to humanity. In the words of God himself, Adam lived to be nine hundred and thirty, yet he transgressed and brought death to himself and all his offspring; whereas Moses, although only having lived to be one hundred and twenty, brought the torah through his obedience and "lit a lamp" for Israel (17:1-4). Secondly, the "life" in Deuteronomy is redefined to mean eternal life. Those who die are not dead, but are simply preserved to be raised in the last times $(27: 14 ; 30: 2 ; 42: 8 ; 50: 2)$. As a matter of fact, 2 Baruch argues, "nothing could be more bitter" than this life, "if there was not to 
be a consummation of all" (21:13-17). Real reward for those who obey the torah, therefore, is in the age to come. ${ }^{81}$

The genius of 2 Baruch, as Henze comments, indeed lies in its ability of integrating multiple strands of Jewish thoughts, especially the seemingly mutually exclusive Deuteronomic and eschatological worldviews. ${ }^{82}$ The apocalyptic wisdom of Baruch does not negate the Mosaic teaching in Deuteronomy; on the contrary, it complements the latter and offers itself as a useful solution to the otherwise endless vicious cycle of sin and punishment in the Deuteronomic scheme. This ingenuity is most clearly demonstrated in Baruch's vision of the "bright and dark waters" (chs. 53-74), which occupies a strategic position in the book's literary structure. ${ }^{83}$

The review of history presented as a vision is precisely the Deuteronomic history. The dark waters symbolize the "bad" periods represented by Adam and the following generations, Israel's enslavement in Egypt, the Amorites and the days of the Judges, Jeroboam, Manasseh, and the Babylonian destruction of Jerusalem and the temple. The bright waters, on the other hand, symbolize the "good" periods of Israelite history, represented by Abrahamic patriarchs, Moses, David and Solomon, Hezekiah, Josiah, and the return from the exile and the rebuilding of the temple. In other words, the selection of the episodes and the judging criterion are entirely in line with the Deuteronomic view of reward and punishment based on obedience to the Mosaic torah. After these twelve periods, Baruch sees a last surge of dark waters, representing the sorrows and woes while the world anticipates the end. They are followed by another surge of bright waters, symbolizing the coming of the Messiah and the consummation of time.

This is how the eschatological worldview has put an end to the vicious cycle of sin and punishment and turned the Deuteronomic promise of reward into permanent good news. The author of 2 Baruch places himself and his audience at the stage of the last dark waters, enduring the tribulations while preparing their hearts in repentance for the restoration. What comes after, the last bright waters, is not only the reward promised by the Deuteronomic scheme, but also the end of this age along with all its afflictions and imperfections, according to the wisdom of Baruch's apocalyptic revelation. The reward is

\footnotetext{
$81 \quad$ See also Burkes, "Life' Redefined."

82 Henze, "Torah and Eschatology," 204.

83 It is the last vision before Baruch writing the epistle and departing from this world. It functions as both an overview and a summary of divine revelation through biblical history and through the eschatological knowledge received by Baruch. The author attaches great significance to it by both describing its visual aspects and giving a detailed verbal explanation by the angel Remiel.
} 
ever lasting, life in the age to come. The eschatological interpretation of the Deuteronomic scheme has thus resolved a dilemma intensified by the crisis of temple destruction.

In terms of its understanding of the torah, therefore, 2 Baruch appears to be even closer to the Mosaic tradition than 4 Ezra. Both claim authority for the wisdom received by their respective protagonist; however, the authority of the "new" revelation must be aligned with the Mosaic torah. Both achieve this by characterizing their protagonist as a type of Moses: 4 Ezra as the second giver of torah, and Baruch as the torah teacher. Both also submit their own wisdom teaching under the authority of Moses, 4 Ezra by grafting the esoteric knowledge it propagates into the Sinaitic torah tradition, and 2 Baruch by presenting an eschatological interpretation to the Deuteronomic scheme and subordinating wisdom teaching to the Deuteronomic worldview enshrined in the name of Moses.

In conclusion, 4 Ezra and 2 Baruch understand and articulate their idea of torah in a way that is characteristic of the sapientialization of the Mosaic tradition in the Second Temple period. This finding is consistent with that of Sanders and many others, that the torah paradigm is taken up by the wisdom tradition and interpreted in the latter's own terms.

However, it is equally important to mark how in the two apocalypses, the wisdom tradition is completely submitted under the authority of the Mosaic torah tradition. As a matter of fact, not only the sapiential tradition, but also the prophetic as well as the apocalyptic strands, are all placed under Mosaic priority. In 4 Ezra this is done by attributing the entire Tanakh as well as all other books of esoteric teaching to Mosaic revelation; in 2 Baruch, on the other hand, Israel's wise leaders in the future will be interpreters of the Mosaic torah, and divine revelations are only found through interpretations of torah. It may indeed be a surprise to many how 4 Ezra and 2 Baruch, representing the epitome of the apocalyptic tradition of Second Temple Judaism, can be utterly Mosaic and Deuteronomic at the same time.

Torah indeed adopted the wisdom lens and voice; but wisdom itself eventually had to gain authority and legitimacy by becoming part of the ancient torah mediated through Moses. Fourth Ezra and Second Baruch did not represent all streams of Second Temple Judaism. Nevertheless, they were certainly not unique in their reverence for the extra-biblical traditions about Moses. Many 
materials they use regarding Moses-for example, as a recipient of esoteric knowledge about the end, or about his being translated to heaven instead of being buried in a tomb-were not their own creation, but expanded Mosaic tradition of the Second Temple period, witnessed also in the legends recorded in other Jewish works such as Jubilees, Testament of Moses, and Liber antiquitatum biblicarum. ${ }^{84}$ The submission of sapiential revelation to Mosaic authority in 4 Ezra and 2 Baruch is rather characteristic of later Second Temple Judaism. ${ }^{85}$ It was through the submission under Mosaic authority that the convergence of diverse traditions was achieved.

A further comment can be made regarding the metaphor of colliding canopies Sanders used to describe the interaction of torah and wisdom. As the Mosaic, sapiential, prophetic and apocalyptic traditions meet in 4 Ezra and 2 Baruch, there is no evidence that the ancient authors perceived any conflict or confrontation between them; instead, the diverse traditions were made to show conformity and continuity with the revelation of Sinai. ${ }^{86}$ The two apocalyptic authors presented "innovative" proposals to deal with a new crisis of national and religious identity, yet they saw themselves not as making changes but adhering steadfast to biblical traditions. ${ }^{87}$ The very choice of the pseudonyms also testifies their approach to be one not of rejection and replacement, but of accommodation, coordination and ultimately reinterpretation of established traditions. ${ }^{88}$ There are also clearly different tendencies shown in 4 Ezra and 2 Baruch. In the former, the established Mosaic tradition needed to be expanded, although even the new expansions must also seek the authority

84 See Najman's Seconding Sinai, as she proposes the concept of a "discourse" around a figure of a founder as a better approach to understanding the so-called pseudepigrapha or "rewritten" scriptures. See also Najman's Losing the Temple, 26-66 (Chapter 2). On the topic of "rewriting" as exegesis and interpretation especially within the discussion of torah and wisdom, see Teeter, "Torah, Wisdom, Composition," and Kratz, "Rewriting Torah."

85 Gabriele Boccaccini, however, perceives the existence of a rival "Enochic Judaism" represented by the books of Enoch, which he believes extended well into the first century CE. See his Middle Judaism, and Beyond Essene Hypothesis. Also according to Collins (Invention of Judaism, 76), the Enochic Book of Similitudes dated to the first century CE "may testify to the persistence of a form of Judaism that was not focused on the torah of Moses into the first century of the Common Era."

86 Cf. Wright, "Sapiential Pedagogy," 168-69, on the harmonious rather than confrontational relationship between torah and wisdom.

87 This dynamic between religious innovation and fidelity to earlier traditions occurred not only after the establishment of the canon, but is even found within the books of the Hebrew Bible. See Levinson, Legal Revision. Although he focuses on the legal tradition only, the same principle has much wider application.

88 Gore-Jones, When Judaism Lost, 218. See also Najman, "How to Make Sense." 
of antiquity and the endorsement of the Mosaic stamp; whereas in the latter, new revelations are to be obtained by returning to old scriptures for fresh understanding. Nonetheless, in both cases religious renewal is made possible through a reworking of established traditions.

Finally, it is not a new idea that scripturalization and the scribal class served as the nexus and crucible for the process of integration of various traditions, ${ }^{89}$ especially the merging of torah and wisdom. Fourth Ezra and Second Baruch, products of the very end of Second Temple Judaism, do not provide evidence for how the process took place, but they do witness the monumental importance of writing and scriptures; and in both their proposed religious renewals, it is the scribal class that will be the core leadership for the future of their faith communities. For 4 Ezra, even the infinite esoteric wisdom (represented by the seventy books) is turned into written torah in order to acquire its divinely derived authority, through Ezra the scribe of the Most High and his five assistant scribes, to be read and understood only by the "wise"; whereas for 2 Baruch, the intermediary between God and the covenant people will be the torah itself, accessible through teachers and interpreters the torah shall bring about—scribes like Baruch himself.

\section{Bibliography}

Allison, Dale C. Jr. The New Moses: A Matthean Typology (Minneapolis: Fortress, 1993). Berger, Peter L. The Sacred Canopy:Elements of a Sociological Theory of Religion (Garden City: Doubleday, 1967).

Berger, Peter L., and Thomas Luckmann. The Social Construction of Reality: A Treatise in the Sociology of Knowledge (Garden City: Doubleday, 1966).

Blenkinsopp, Joseph. Wisdom and Law in the Old Testament: The Ordering of Life in Israel and Early Judaism, rev. ed. (Oxford: Oxford University Press, 1995).

Boccaccini, Gabriele. Middle Judaism:Jewish Thought 300 BCE to 200 CE (Minneapolis: Fortress, 1991).

Boccaccini, Gabriele. Beyond the Essene Hypothesis: The Parting of the Ways between Qumran and Enochic Judaism (Grand Rapids: Eerdmans, 1998).

Bogaert, Pierre. L'Apocalypse syriaque de Baruch (Paris: Cerf, 1969).

Botha, Philippus J. "Interpreting 'Torah' in Psalm 1 in the Light of Psalm 119." HTS Teologiese Studies/Theological Studies 68 (2012). doi 10.4102/hts.v68i1.1274.

Burkes, Shannon. "'Life' Redefined: Wisdom and Law in Fourth Ezra and Second Baruch." Catholic Biblical Quarterly 63 (2001), 55-71.

89 See, for example, the two books of Carr, Tablet of Heart and Formation of Hebrew Bible. 
Carr, David M. Writing on the Tablet of the Heart: Origin of Scripture and Literature (New York: Oxford University Press, 2005).

Carr, David M. The Formation of the Hebrew Bible: A New Reconstruction (New York: Oxford University Press, 2012).

Collins, John J. Jewish Wisdom in the Hellenistic Age (Louisville: Westminster John Knox, 1997).

Collins, John J. "From Prophecy to Apocalypticism: The Expectation of the End." In The Origins of Apocalypticism in Judaism and Christianity, ed. John J. Collins. Vol. 1 of The Encyclopedia of Apocalypticism, ed. John J. Collins, Bernard McGinn and Stephen J. Stein (New York: Continuum, 1998), 129-61.

Collins, John J. Apocalyptic Imagination: An Introduction to Jewish Apocalyptic Literature, 2nd ed. (Grand Rapids: Eerdmans, 1998).

Collins, John J. "The Transformation of the Torah in Second Temple Judaism." Journal for the Study of Judaism 43 (2012), 455-74.

Collins, John J. The Invention of Judaism: Torah and Jewish Identity from Deuteronomy to Paul (Oakland: University of California Press, 2017).

Deißler, Alfons. Psalm 119 (118) und seine Theologie (Munich: Zink, 1955).

Finsterbusch, Karin. "Yahweh's Torah and the Praying 'I' in Psalm 119." In Wisdom and Torah: The Reception of 'Torah' in the Wisdom Literature of the Second Temple Period, ed. Bernd U. Schipper and D. Andrew Teeter (Leiden: Brill, 2013), 119-35.

Fishbane, Michael. "Torah and Tradition." In Tradition and Theology in the Old Testament, ed. Douglas A. Knight (Philadelphia: Fortress, 1977), 275-30o.

Freedman, David N., Jeffrey C. Geoghegan, and Andrew Welch. Psalm 119: The Exaltation of Torah (Winona Lake: Eisenbrauns, 1999).

Gore-Jones, Lydia. "The Unity and Coherence of 4 Ezra: Crisis, Response, and Authorial Intention." Journal for the Study of Judaism 47 (2016), 212-35.

Gore-Jones, Lydia. When Judaism Lost the Temple: Crisis and Response in 4 Ezra and 2 Baruch (Turnhout: Brepols, 2020).

Gurtner, Daniel M. Second Baruch: A Critical Edition of the Syriac Text. With Greek and Latin Fragments, English Translation, Introduction, and Concordances (New York: T\&T Clark, 2009).

Hanson, Paul D. The Dawn of Apocalyptic (Philadelphia: Fortress, 1975).

Henze, Matthias. "Qoheleth and the Syriac Apocalypse of Baruch." Vetus Testamentum $58(2008), 28-43$.

Henze, Matthias. "Torah and Eschatology in the Syriac Apocalypse of Baruch." In The Significance of Sinai: Traditions about Sinai and Divine Revelation in Judaism and Christianity, ed. George J. Brooke, Hindy Najman, and Loren T. Stuckenbruck (Leiden: Brill, 2008), 201-15.

Henze, Matthias. Jewish Apocalypticism in Late First Century Israel: Reading Second Baruch in Context (Tübingen: Mohr Siebeck, 2011). 
Hogan, Karina Martin. "The Meanings of tôrâ in 4 Ezra." Journal for the Study of Judaism 38 (2007), 530-52.

Hogan, Karina Martin. Theologies in Conflict in 4 Ezra: Wisdom, Debate, and Apocalyptic Solution (Leiden: Brill, 2008).

Kaiser, Otto. "Covenant and Law in Ben Sira." In Covenant as Context: Essays in Honour of E.W. Nicholson, ed. Andrew D.H. Mayes and Robert B. Salters (Oxford: Oxford University Press, 2003), 235-6o.

Kim, Daewoong. "Wisdom and Apocalyptic in 2 Baruch." Henoch 33 (2011), 250-74.

Klijn, A.F.J. “2 (Syriac Apocalypse of) Baruch.” In The Old Testament Pseudepigrapha, ed. James H. Charlesworth, 2 vols. (New York: Doubleday, 1983-1985), 1:615-52.

Knibb, Michael A. "The Second Book of 2 Esdras." In The First and Second Books of Esdras, Richard J. Coggins and Michael. A. Knibb (Cambridge: Cambridge University Press, 1979), 76-305.

Knibb, Michael A. "Apocalyptic and Wisdom in 4 Ezra." Journal for the Study of Judaism 13 (1982), 56-74.

Knowles, Michael P. "Moses, the Law and the Unity of 4 Ezra." Novum Testamentum 31 (1989), 257-74.

Kratz, Reinhard G. "Rewriting Torah in the Hebrew Bible and the Dead Sea Scrolls." In Wisdom and Torah: The Reception of 'Torah' in the Wisdom Literature of the Second Temple Period, ed. Bernd U. Schipper and D. Andrew Teeter (Leiden: Brill, 2013), 273-93.

Krüger, Thomas. "Law and Wisdom According to Deut 4:5-8." In Wisdom and Torah: The Reception of 'Torah' in the Wisdom Literature of the Second Temple Period, ed. Bernd U. Schipper and D. Andrew Teeter (Leiden: Brill, 2013), 35-54.

Levenson, Jon D. "The Source of Torah: Psalm 119 and the Modes of Revelation in Second Temple Judaism." In Ancient Israelite Religion: Essays in Honor of Frank Moore Cross, ed. Patrick D. Miller, Jr., Paul D. Hanson, and S. Dean McBride (Philadelphia: Fortress, 1987), 559-74.

Levinson, Bernard M. Legal Revision and Religious Renewal in Ancient Israel (Cambridge: Cambridge University Press, 2008).

Longenecker, Bruce W. 2 Esdras (Sheffield: Sheffield Academic, 1995).

Longenecker, Bruce W. "Locating 4 Ezra: A Consideration of Its Social Setting and Function." Journal for the Study of Judaism 28 (1997), 271-93.

Metzger, Bruce M. “The Fourth Book of Ezra: A New Translation and Introduction.” In The Old Testament Pseudepigrapha, ed. James H. Charlesworth, 2 vols. (New York: Doubleday, 1983-1985), 1:516-59.

Moo, Jonathan A. Creation, Nature and Hope in 4 Ezra (Göttingen: Vandenhoeck \& Ruprecht, 2011).

Mroczek, Eva. The Literary Imagination in Jewish Antiquity (New York: Oxford University Press, 2016). 
Müller, Reinhard. "The Blinded Eyes of the Wise." In Wisdom and Torah: The Reception of 'Torah' in the Wisdom Literature of the Second Temple Period, ed. Bernd U. Schipper and D. Andrew Teeter (Leiden: Brill, 2013), 9-33.

Murphy, Frederick J. The Structure and Meaning of Second Baruch (Atlanta: Scholars Press, 1985).

Najman, Hindy. Seconding Sinai: The Development of Mosaic Discourse in Second Temple Judaism (Leiden: Brill, 2003).

Najman, Hindy. "How to Make Sense of Pseudonymous Attribution: The Case of 4 Ezra and 2 Baruch." In A Companion to Biblical Interpretation in Early Judaism, ed. Matthias Henze (Grand Rapids: Eerdmans, 2012), 308-36.

Najman, Hindy. Losing the Temple and Recovering the Future: An Analysis of 4 Ezra (Cambridge: Cambridge University Press, 2014).

Nickelsburg, George W.E. "Torah and the Deuteronomic Scheme in the Apocrypha and Pseudepigrapha: Variations on a Theme and Some Noteworthy Examples of Its Absence." In Das Gesetz im frühen Judentum und im Neuen Testament: Festschrift für Christoph Burchard zum 75. Geburtstag, ed. Dieter Sänger and Matthias Konradt (Göttingen: Vandenhoeck \& Ruprecht, 2006), 222-35.

Östborn, Gunnar. Tôrâ in the Old Testament: A Semantic Study (Lund: Ohlsson, 1945).

Rad, Gerhard von. Theologie des Alten Testaments, 4th ed., 2 vols. (Munich: Kaiser, 1965).

Reynolds, Kent A. Torah as Teacher: The Exemplary Torah Student in Psalm 119 (Leiden: Brill, 2010).

Rosenfeld, Ben-Zion. "Sage and Temple in Rabbinic Thought after the Destruction of the Second Temple." Journal for the Study of Judaism 28 (1997), 437-64.

Russell, David S. The Method and Message of Jewish Apocalyptic, 200 BC-AD 100 (London: SCM, 1964).

Sanders, Jack T. "When Sacred Canopies Collide." Journal for the Study of Judaism 32 (2001), 121-36.

Sayler, Gwendolyn B. Have the Promises Failed? A Literary Analysis of 2 Baruch (Chico: Scholars Press, 1984).

Schipper, Bernd U., and D. Andrew Teeter. "Introduction." In Wisdom and Torah: The Reception of 'Torah' in the Wisdom Literature of the Second Temple Period, ed. Schipper and Teeter (Leiden: Brill, 2013), 1-8.

Schipper, Bernd U. "When Wisdom Is Not Enough! The Discourse on Wisdom and Torah and the Composition of the Book of Proverbs." In Wisdom and Torah: The Reception of 'Torah' in the Wisdom Literature of the Second Temple Period, ed. Bernd U. Schipper and D. Andrew Teeter (Leiden: Brill, 2013), 55-79.

Schnabel, Eckhard J. Law and Wisdom from Ben Sira to Paul: A Tradition Historical Enquiry into the Relation of Law, Wisdom, and Ethics (Tübingen: Mohr Siebeck, 1985). Seybold, Klaus. Die Psalmen (Tübingen: Mohr Siebeck, 1996). 
Sheppard, Gerald T. Wisdom as a Hermeneutical Construct: A Study in the Sapientializing of the Old Testament (Berlin: De Gruyter, 1980).

Stone, Michael E. Fourth Ezra: A Commentary on the Book of Fourth Ezra (Minneapolis: Fortress, 1990).

Stone, Michael E. and Matthias Henze. 4 Ezra and 2 Baruch:Translations, Introductions, and Notes (Minneapolis: Fortress, 2013).

Teeter, D. Andrew. "Torah, Wisdom, and the Composition of Rewritten Scripture: Jubilees and ${ }_{11} \mathrm{QPs}^{\mathrm{a}}$ in Comparative Perspective." In Wisdom and Torah: The Reception of 'Torah' in the Wisdom Literature of the Second Temple Period, ed. Bernd U. Schipper and D. Andrew Teeter (Leiden: Brill, 2013), 233-72.

Tooman, William A. "Wisdom and Torah at Qumran: Evidence from the Sapiential Texts." In Wisdom and Torah: The Reception of 'Torah' in the Wisdom Literature of the Second Temple Period, ed. Bernd U. Schipper and D. Andrew Teeter (Leiden: Brill, 2013), 203-32.

Uusimäki, Elisa. Turning Proverbs towards Torah: An Analysis of 4Q525 (Leiden: Brill, 2016).

Vermes, Geza. "The Torah Is a Light." Vetus Testamentum 8 (1958), 436-38.

Weinfeld, Moshe. Deuteronomy and the Deuteronomic School (Oxford: Clarendon, 1972).

Whitters, Mark F. The Epistle of Second Baruch: A Study in Form and Message (London: Sheffield Academic, 2003).

Wright, Benjamin G. III. “Torah and Sapiential Pedagogy in the Book of Ben Sira." In Wisdom and Torah: The Reception of 'Torah' in the Wisdom Literature of the Second Temple Period, ed. Bernd U. Schipper and D. Andrew Teeter (Leiden: Brill, 2013), 157-86.

Yarbro Collins, Adela. “The Influence of Daniel on the New Testament." In Daniel: A Commentary on the Book of Daniel, John J. Collins (Minneapolis: Fortress, 1993), 90-112.

Zenger, Erich. "Torafrömmigkeit: Beobachtungen zum poetischen und theologischen Profil von Psalm 119." In Freiheit und Recht: Festschrift für Frank Crüsemann zum 65. Geburtstag, ed. Christof Hardmeier, Rainer Kessler, and Andreas Ruwe (Gütersloh: Kaiser, 2003), 380-96. 